\title{
PROFESSZIONALIZÁLÓDÓ FESZTIVÁL ÖNKÉNTESSÉG EGY KAPCSOLATHÁLÓZATI KUTATÁS TÜKRÉBEN - ESETTANULMÁNY
}

\author{
BODOR-ERANUS ELIZA ${ }^{1}$ - BOCSKOR ÁKOS² - \\ SZVETELSZKY ZSUZSANNA ${ }^{3}$ - TAKÁCS KÁROLY ${ }^{4}$ - VIT ESZTER ${ }^{5}$ - \\ SAMU FLÓRA ${ }^{6}$ - GALÁNTAI JÚLIA - PÉTERVÁRI JUDIT
}

DOI: https://doi.org/10.53585/OnkSzem.2021.2.110-124

\section{Absztrakt}

A hazai fesztivál önkéntes szervezeten belül kialakult három szintú hierarchia (önkéntesek, mentorok, koordinátorok) jól tükrözi a szervezeti múködés professzionalizálódását. A középvezetői szintet képviselő mentori pozíció egyedüláló tanulási lehetőséget jelent az önkéntes programba jelentkező fiatalok számára. A mentorok 20-30 önkéntesből álló csoport munkájáért felelnek a fesztivál ideje alatt, lehetővé téve olyan - a munkaerőpiacon is jól hasznosítható - készségek elsajátítását, mint például a csapatmunka szervezése és számonkérése, a csoportos és csoportközti kommunikáció, továbbá a feladat-, illetve humánerőforrás koordinációja. Az esettanulmány alapját képező kutatás a Sziget Fesztivál ideje alatt kapcsolathálózati módszerekkel vizsgálta a fesztivál önkéntesek mentori szintjét 2018-ban. A kapcsolathálózati elemzés elsődleges értéke abban van, hogy rámutat a klasszikus feladatés az érzelmi vezető funkcióinak az önkéntesek közösségében való megjelenésére, amelyek ismeretében sikeresebb és eredményesebb vezetői döntések alakíthatók ki.

Kulcsszavak: fesztivál önkéntesség, Sziget Fesztivál, kapcsolathálók, együttmüködés, kommunikáció, elégedettség, elköteleződés,

\footnotetext{
${ }^{1}$ Bodor-Eranus Eliza (PhD), szociológus, tudományos munkatárs, Társadalomtudományi Kutatóközpont, CSSRECENS

2 Bocskor Ákos, szociológus, egyetemi tanársegéd, Budapesti Corvinus Egyetem, Kommunikáció és Szociológia Intézet; tudományos segédmunkatárs, Társadalomtudományi Kutatóközpont, CSS-RECENS

3 Szvetelszky Zsuzsanna (PhD), szociálpszichológus, tudományos munkatárs, Társadalomtudományi Kutatóközpont, CSS-RECENS

${ }^{4}$ Takács Károly (PhD), szociológus, egyetemi tanár, The Institute for Analytical Sociology, Linköping University

${ }^{5}$ Vit Eszter, szociológus, tudományos segédmunkatárs, The Institute for Analytical Sociology, Linköping University

6 Samu Flóra, szociológus, tudományos segédmunkatárs, The Institute for Analytical Sociology, Linköping University

7 Galántai Júlia, szociológus, tudományos segédmunkatárs, The Institute for Analytical Sociology, Linköping University

${ }^{8}$ Pétervári Judit (Ph.D), kísérleti pszichológus, School of Biological and Chemical Sciences, Queen Mary University of London
} 
Professionalization of festival volunteering from the perspective of a social network research - Case study

ELIZA BODOR-ERANUS - ÁKOS BOCSKOR - ZSUZSANNA SZVETELSZKY - KÁROLY TAKÁCS - ESZTER VIT - FLÓRA SAMU - JÚLIA GALÁNTAI - JUDIT PÉTERVÁRI

\section{Abstract}

The three-level organizational hierarchy (volunteers, mentors, coordinators) of the Hungarian festival volunteer organization reflects its professionalisation. The mentoring position, representing the middle level of the organization, is a unique learning opportunity for young people applying for the voluntary programme. Mentors are responsible for the work of a group of 20-30 volunteers during the festival, enabling them to acquire skills that can be used in the labour market, such as organising and checking of teamwork, in-group and inter-group communication as well as coordinating tasks and human resources.

Our research investigated the mentor level of festival volunteers during the biggest Hungarian music festival, the Sziget Festival in 2018 with social analysis methodology. The primary value of network analysis is that it highlights the emergence of the functions of the classical task leader and emotional leader in the volunteer community which can be used to make management decisions more successful and effective.

Keywords: festival volunteering, Sziget Festival, social networks, cooperation, communication, job satisfaction, commitment,

\section{BEVEZETÉS}

A fiatal munkavállalók tapasztalat hiányában elhelyezkedési nehézségekbe ütköznek és bérhátránnyal indulnak a tapasztaltabb munkavállalókhoz képest. Így az önkéntes és gyakornoki munka fontos mérföldkövet jelent az egyéni karrierépítésben (Frenette 2013): az itt elsajátított képességek, készségek segítik őket a tapasztalatszerzésben. Ilyen lehetőség a fesztivál önkéntesek mentori (csoportvezetői) feladatköre is, melynek során a fiataloknak arra nyílik lehetőségük, hogy a könnyúzenei fesztiválokon 20-30 önkéntesből álló csoport munkáját irányítsák, számon kérjék és ellenőrizzék, a munka során felmerülő átszervezéseket menedzseljék, elősegítve nem csak a saját, hanem a fiatal önkéntesek munkaerőpiaci tapasztalatszerzését is.

A hatékony szervezeti tanulás és tanítás feltétele a dolgozói elkötelezettség és elégedettség (Gjelsvik 2002), amely attitűdökre jelentős hatással van a munkavállalókat körülvevő társadalmi struktúra (Morrison 2002). Fontos tehát feltérképezni azokat a formális és informális kapcsolatokat, amelyek az önkéntes-mentorok szervezeti elkötelezettségét és elégedettségét alakíthatják, hiszen azok befolyásolhatják a szervezeti hierarchiában alájuk tartozó önkéntesek tanulási lehetőségeit. Az önkéntesek elköteleződésére, elégedettségére, 
és hatékony tanulásukra pozitív hatással van a folyamatos és azonnali visszajelzés és felügyelet (Cnaan - Cascio 1998), és erre nyújt megfelelő lehetőséget a szervezet hierarchikus felépítése (Joseph et al. 2016). Az önkéntes programban való részvétel felhívás alapú, azonban a szervezet professzionalizálódását jól alátámasztja a projektre épülő toborzási folyamat, speciális munkakultúra és a három szervezeti szintből - koordinátorokból, mentorokból, önkéntesekből - álló szervezeti hierarchia.

Esettanulmányunk ${ }^{9}$ célja bemutatni a három szervezeti szintből álló önkéntes szervezet középvezetőinek, mentorainak sikeres együttműködési jellemzőit, továbbá rávilágítani a kapcsolathálózati felmérések jelentőségére az ilyen típusú szervezetek esetében. ${ }^{10}$

\section{A FESZTIVÁL ÖNKÉNTESEK SZERVEZETI FELÉPÍTÉSE}

A hazai, legnagyobb könnyűzenei fesztiválok, mint például a Sziget, Volt, Balaton Sound, önkénteseinek bázisát a Fesztivál Önkéntes Központ (FÖK) szervezi. A FÖK 2011-ben alakult és az önkéntesek számát és összetételét évről évre a Sziget Fesztivál, a Volt és a Balaton Sound igényeihez igazítja, az elmúlt évekre vonatkozóan növekvő tendenciában: míg kezdetben 20 önkéntessel kezdték el a munkát az utolsó Sziget Fesztiválon, 2019-ben már közel 1200 önkéntessel segítették a fesztivál munkáját.

A fesztivál önkéntesek három szinten látják el feladataikat a Fesztivál Önkéntes Központban. Egyrészt az önkéntesek (adott feladathoz rendelt önkéntes munkaerő, mint például a sportpályaépítés, zenekarok kísérése, színpadépítés, belépés - kilépés felügyelete, környezetvédelmi munkák, és egyéb háttérmunkák), másrészt a mentorok (az adott feladatokat végző önkéntesek munkájának szervezői, ellenőrzői, gyakorlatilag csoportvezetői, középvezetői funkcióval), és harmadrészt a koordinátorok (az önkéntesek és mentorok munkájának szervezése, koordinációja) szintjén.

A Fesztivál Önkéntes Központ nem egy önálló szervezet, hanem inkább egy brand, mely több nonprofit és forprofit szereplő együttmúködéséből született, egyesítve a különböző szektorok tapasztalatait, igényeit és szintetizálva a szereplők gondolkodásmódját. Mint ahogy a FÖK

\footnotetext{
${ }^{9}$ Az esettanulmány alapját is képező kutatás a European Research Council (ERC), az Európai Unió Horizon 2020 Kutatási és Innovációs Program keretében valósult meg (projekt neve: EVILTONGUE, támogatási megállapodás száma: No. 648693).

${ }^{10}$ A kutatás helyszínén nyújtott segítségért köszönettel tartozunk a Sziget Produkciós Irodának, a Fesztivál Önkéntes Központnak és a winwinwin kft.-nek.
} 
sem, a branden belül futó, 6 éves múltra visszatekintő mentorképzési program sem köthető egy konkrét szervezethez. A HelloMentor program, egy komplex felkészítési módszertan keretén belül készíti fel a mentorokat a helyszíni munka kihívásaira, önálló nevet és brandet 2018-ban kapott, és évről évre igyekszik követni a régi és új szereplők igényeit.

A fesztivál önkéntesek szervezeti felépítésében a mentorok feladatai speciálisak: egyrészt az önkéntesekkel kapcsolatos feladataik, másrészt a HelloMentor programmal és önkéntes bázissal kapcsolatos teendőik vannak. Középvezetőként ők fogadják az önkénteseket a fesztivál első napján, ők osztják szét az önkéntesek munkaruhájaként szolgáló megkülönböztető pólóikat, majd felelnek az önkéntesek munkájáért, segítik a kommunikációt és problémamegoldást az egy feladaton dolgozó önkéntesek és fizetett alkalmazottak között, kezelik az újratervezésből fakadó munkabeosztást, lelkileg és adminisztrációs szempontból támogatják az önkénteseket. Mindemelett a mentorok gondozzák a Fesztivál Önkéntes Központ és HelloMentor program promotálását a Civil szigeten, ők állítják fel és üzemeltetik az erre a célra létrehozott sátrat.

A mentorok feladatai gyakorlatilag lefedik a nap 24 óráját, az olyan helyzetekben, amikor pihennek, vagy szabadnapjuk van, mentor-párjuk segíti munkájukat. Szervezeten belül speciális jogosultságaik vannak: külön zárt területtel, bázisrésszel rendelkeznek a nagy önkéntes bázison belül, ahol számítógéphez, telefontöltőhöz, hűtőhöz is hozzáférhetnek. A mentorok a fesztivál ideje alatt napi szintű megbeszéléseken vesznek részt, jellemzően a délelőtti órákban, ahol tapasztalataikat megosztják és megbeszélik egymással, illetve a FÖK koordinációjával. Normaszegés esetén a mentoroknak nincs végrehajtási jogosultságuk, ellenben közvetíteniük kell a problémákat az ilyen jogosultsággal rendelkező koordináció felé. Az esettanulmány alapját képező kutatásunk a fesztivál önkéntes szervezet középvezetői, mentori szintjére fókuszált a 2018-as Sziget Fesztivál ideje alatt.

\section{KUTATÁSI CÉLCSOPORT ÉS MÓDSZERTAN}

Vizsgálatunkban a 2018-as Sziget Fesztivál önkénteseinek összes mentora, azaz 32 fő vett részt. A fesztivál előtti és utáni kérdőívek kitöltési aránya 100 százalékos volt, a napi dinamikus felmérések esetében átlagosan 80 százalék körüli volt (az alacsonyabb válaszadás nagyrészt a szabadnapoknak volt köszönhető) és összesen 21 interjú készült el a fesztivál végére. A mentorok között fele arányban voltak a nők és férfiak, majdnem negyedük előző 
évben/években is mentor volt, 14 - 14 fő a Sound vagy Volt-fesztivál egyikén, 4 fő mindkettőn részt vett a Sziget Fesztivált megelőzően. Feladatkörönként (melyeket a FÖK előzetesen meghatározott) az alábbi megoszlásban szerepeltek a mentorok: 12-en "szellemi", 9-en „fizikai”, 5-en „kemping” és 6-an „program” tevékenységek szerint voltak beosztva. Ezek a kategóriák átfogóak és tematikusan integrálták az adott mentorhoz tartozó önkéntesek feladatbeosztását. A férfiak átlagos életkora 22,1 év, a nőké 20,6 év volt. A mentorok közül 6 volt budapesti, 26 pedig vidékről érkezett, hatan rendelkeztek főiskolai vagy egyetemi végzettséggel és huszonöten az adatfelvétel idején valamelyik felsőfokú intézménynek a hallgatói voltak.

A mentorprogramot 2018-ban 27-en kezdték el, a többiek ennél régebben, a legrégebbi mentor 2014-ben vett részt először a programban. Volt 20 olyan mentor, aki előzőleg már részt vett a FÖK munkájában önkéntesként. Szervezeti elégedettségük magasnak tekinthető, 10 fokú skálán 8,87 volt az átlagos elégedettségük és senki sem adott 6-nál gyengébb értéket az „Összességében mennyire vagy elégedett a mentorsággal?” kérdésre. Ötfokú skálán mérve, 26 mentor szerint a mentorság kifejezetten sikerélményt ad (5-ös érték).

2018-ban, a Sziget Fesztivál ideje alatt, augusztus 2-14 között a FÖK mentori szintjét három kutatási módszerrel vizsgáltuk:

1. Amunkahelyi elégedettségre, elköteleződésre és együttműködésre vonatkozó kérdőíves felméréssel a fesztivált megelőzően, közben és azt követően,

2. dinamikus, naponta kétszeri okosórán történő kapcsolatháló-felméréssel a formális- és informális kommunikációról, illetve együttmúködésről, továbbá a munkavégzés nehézségeiről, kiegészítve a hangulatukra, illetve az önkéntes csoportjuk hangulatára vonatkozó kérdésekkel,

3. személyes interjúkkal.

\section{SZERVEZETI SAJÁTOSSÁGOK}

\section{Az önkéntes munkavégzés viszonyai}

A FÖK-ön belül, az önkéntes szervezetben alá-fölé- és mellérendeltségi viszonyok is vannak. Az alá-fölé rendeltségi viszonyok a szervezeten belül értelmezhetők, míg a mellérendeltségi viszonyok a más (jellemzően fizetett) munkaerővel való közös munka során értelmezhetők. 
Szervezeten belül a koordináció-mentorok közötti viszony informálisnak, barátinak volt tekinthető. Már az első találkozás után voltak közös szabadidős tevékenységek, melyek során kialakultak közöttük a közvetlen kommunikáció formái. Amíg mindenki együttműködött, nem volt érezhető a hierarchia, azonban szabálysértés esetén a FÖK koordinátorai határozott fellépése volt tapasztalható. A mentorok mentorcsoporton belüli viszonya is barátinak, támogatónak bizonyult. Egymás mellett sátoroztak (már a „kisfesztiválokon”, azaz a Szigetet megelőzően is), egymásra támaszkodtak, a személyes konfliktusokat egymással megbeszélték, ezeknek köszönhetően kialakult a mentor-identitás. A mentor-párok meghatározása különös egymásrautaltsági helyzeteket teremtettek, hiszen egy önkéntes csoportnak egy mentora volt, de annak szabadnapján az önkéntesek a mentor-párhoz fordultak. Érdekes a mentorpárok kiválasztása: nem lehettek barátok, mert akkor nem tudtak együtt koncertekre menni, de ellenségek sem lehettek, hiszen akkor nem tudtak együttmúködni. Ezzel szemben a mentor - önkéntes viszony már hierarchiát tükrözött, azonban ez a viszony is kellően laza kellett legyen ahhoz, hogy az önkéntesek csoportvezetőként elfogadják a mentorokat.

Bár nem képezte a kutatás tárgyát, de a szervezeti múködés és a mentorok feladatkörének megértéséhez szükséges értelmezni a szervezeti határokon túlmutató, azonban közvetlenül az önkéntes munkához kapcsolható, önkéntes-csoportvezető (fizetett alkalmazott) mellérendeltségi viszonyt is, amikor egy feladaton dolgoztak önkéntesek és fizetett alkalmazottak. A mellérendeltség ellenére ez egyben egy hierarchikus viszony is: például amikor a fesztiválszervező technikai osztály vezetője szabta meg, hol legyen a kerítés és meddig legyen textilháló, ilyenkor ő rendelkezett a feladatbeosztással, az önkéntesek ilyenkor a feladat végrehajtóiként dolgoztak. A mentorokra ebben a viszonylatban (mentorcsoportvezető viszony) mediátori szerep jutott, hiszen kvázi egyenrangú és együttmúködő félként ők hidalták át az önkéntesek és csoportvezetők között felmerülő problémákat, nézeteltéréseket, védték az önkéntesek érdekeit.

A FÖK-ön belül erős volt a szenioritás-junioritás alapon értelmezhető viszony is, ugyanis a régi mentorokat elismerték, segítségüket, tanácsukat kérték. A szenior mentorok már kiemelt feladatokat is végezhettek, például a képzések során szekciót vezethettek.

\section{Az önkéntes munkavégzés normái}

Az önkénteseknél a feladattudatosságot különböző szabályokkal érték el a FÖK koordinátorai. Ilyen szabály volt például, hogy minden önkéntes-szintnek megvolt a területi lehatárolása, 
egymás területeire („helyeire”) nem léphettek be, így az önkéntesek a mentoroknak fenntartott helyére, vagy a mentorok a koordinátoroknak fenntartott területére nem mehettek be. A szabad jelenlétek alkalmával („amikor lézengtek”) is elkülönültek, csak a célok teljesítése miatt vegyültek - kivéve azokat a koordinátorokat, akik voltak már mentorok is: ők több időt töltöttek a mentorokkal informálisan is. További szabály volt, hogy a bázis területén nem lehetett inni, csak a „backstage-ben", s a mentoroknak egy egységnyi alkohol volt megengedett hatóránként, így a backstage-ben kialakult a bázison belüli társasági élet. Informális szabály volt, hogy akik ismerőssel érkeztek, általában egymás mellett sátoroztak, vigyáztak egymás sátraira, értékeire, eső esetén behúzták egymás sátrainak zipzárját, és ha valaki a sátornál felejtett valamit, bevitték neki a bázisra. A rendkívül intenzív együttlétből fakadóan baráti kapcsolatok alakultak ki, kisebb csoportokban közlekedtek, étkeztek.

A mentorok esetében hamar kialakult a mentor-identitás, erősen összetartó közösséget alkottak. Nyílt ellenségeskedés nem volt jellemző, szeretetteljesen, többé-kevésbé elfogadóan viszonyultak egymáshoz. Probléma esetén jellemzően nagyon készséges és önzetlen volt a segítségnyújtás. Azonban a koordináció részéről váratlanul és plusz megterheléssel járó feladatot nem mindig szívesen vállalták el.

\section{Az önkéntes munkavégzésre ható tényező: a hangulat}

A fesztivál ideje alatt a résztvevő mentorok hangulatát alapvetően a következő tényezők határozták meg:

- a feladatkör nehézsége: a „fizikai” munka (mint például színpadépítés és -bontás) volt a legnehezebb, főleg a fesztivál elején és végén; a „program” és a „szellemi” csoportokba tartozók érezték magukat a legjobban; a „kemping” csoport tagjai számára a fesztivál elején volt megterhelő a munka, de a végére nagyon lazává vált,

- a szezon-fáradság: az önkéntes program előírása szerint a mentoroknak legalább egy kisfesztiválon részt kell venniük a Sziget Fesztivál előtt, azonban két kisfesztiválon való részvétel jelentősen megterhelte a mentorok teherbíró képességét,

- a fesztivál-fáradság: a fesztivál elején sokkal dinamikusabbak voltak a mentorok a fesztivál végéhez képest, amit jelentősen befolyásolt az is, hogy a mentoroknak már 4-6 nappal a fesztivál megkezdése előtt kint kellett lenniük a terepen ahhoz, hogy tudják fogadni önkénteseiket. 
A hangulat alakulását naponta kétszer mértük: délelőtt és délután okosórán kellett kitölteniük egy rövid kérdőívet. A négy mentor-csoportban a hangulat az 1. ábrán látható módon alakult a fesztivál ideje alatt.

1. ábra A hangulat alakulása mentor-csoportonként az egyes napszakokban, a Sziget Fesztivál ideje alatt, 2018-ban.

Hangulat a „fizikai” mentorcsoport átlagolt válaszai alapján napszakonként ( $n=9 ; \mathrm{N}=32$ )

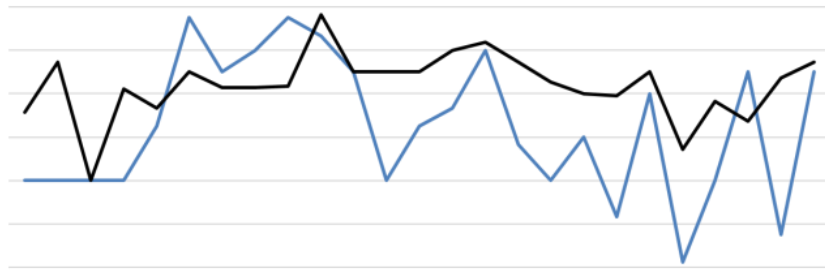

$\begin{array}{lllllllllllllllllllllllll}02 & 03 & 03 & 04 & 04 & 05 & 05 & 06 & 06 & 07 & 07 & 08 & 08 & 09 & 09 & 10 & 10 & 11 & 11 & 12 & 12 & 13 & 13 & 14 & 14\end{array}$ du de du de du de du de du de du de du de du de du de du de du de du de du —fizikai -átlag

Hangulat a „program” mentorcsoport átlagolt válaszai alapján napszakonként $(n=6 ; N=32)$

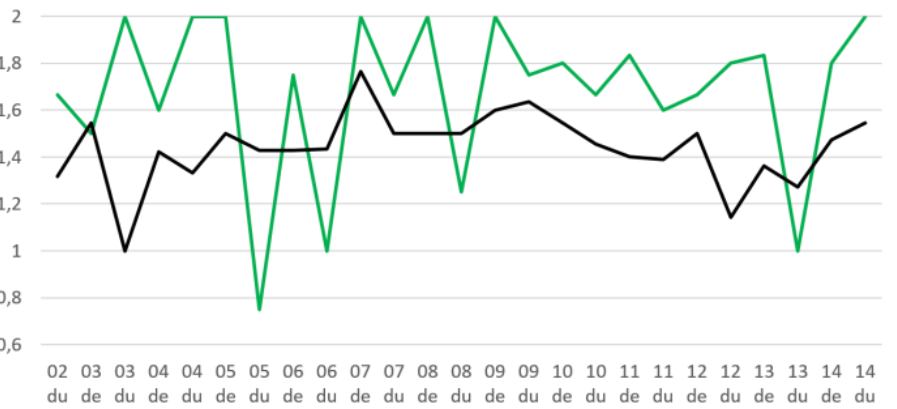

- program —átlag
Hangulat a „kemping” mentorcsoport átlagolt válaszai alapján napszakonként $(\mathrm{n}=5 ; \mathrm{N}=32$ )

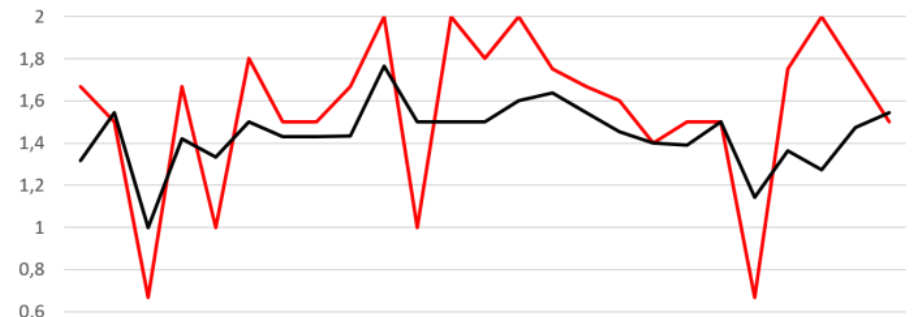

$\begin{array}{lllllllllllllllllllllllll}02 & 03 & 03 & 04 & 04 & 05 & 05 & 06 & 06 & 07 & 07 & 08 & 08 & 09 & 09 & 10 & 10 & 11 & 11 & 12 & 12 & 13 & 13 & 14 & 14\end{array}$ du de du de du de du de du de du de du de du de du de du de du de du de du

$$
\text { —kemping —átlag }
$$

Hangulat a „szellemi” mentorcsoport átlagolt válaszai alapján napszakonként ( $\mathrm{n}=12 ; \mathrm{N}=32$ )

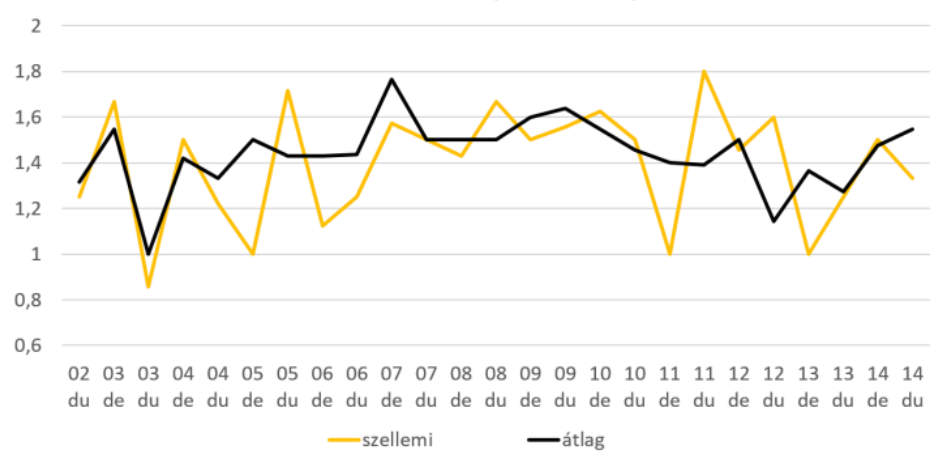

-szellemi - -átlag

Forrás: Az az adott csoportba sorolt mentorok átlagát (színes vonal) tükrözi az összes, 32 mentor átlagához (fekete vonal) képest. A hangulat alakulását naponta kétszer mértük az okosórán kitöltött kérdőív segítségével, a „Milyen volt a hangulat a csoportodban?" kérdéssel, 4 fokú skálán.

A mentor-csoportok létszáma: „fizikai” =9, „kemping” =5, „program” =6 és „szellemi” =12 fö.

\section{KAPCSOLATHÁLÓZATI SAJÁTOSSÁGOK, KUTATÁSI EREDMÉNYEK}

\section{Együttmüködés}

A formális és informális együttmúködést a fesztivált megelőzően, közben és követően mértük, tableten kitöltött kérdőíves felmérés során, melyet összehasonlítottunk a munkahelyi elégedettségükkel és elköteleződésükkel (2. ábra). Az együttműködést a kapcsolathálózati kutatásokban alkalmazott névgeneráló kérdésekkel tártuk fel (a munkavégzésből fakadóan kivel kell, illetve kivel szeret együttmúködni) a mentorok és koordinátorok esetében. 
Eredményeink alapján a 2018-as Sziget Fesztivál koordinátorai és mentorai szorosan együttmúködtek egymással. A mentoroknak kiemelt szerepük volt az együttmúködés szempontjából, a mentorok „szellemi” munkacsoportjának több tagja is központi helyet foglalt el az együttmúködési hálóban, nem voltak köztük perifériára szoruló egyének. A kutatás során a kötelező együttműködési háló sűrűsége, a jelölések száma csökkent (53 százalékról $\square 27$ százalékra $\square 29$ százalékra), ami részben magyarázható azzal, hogy az idő elteltével a feladatvégzés rutinossá vált a mentorok önállósodtak.

2. ábra A formális (kötelező) és informális együttmüködés kapcsolathálója a koordinátorok és mentorok esetében a Sziget Fesztivált megelözően, közben és végén, 2018-ban.

Kötelező együttmüködés 1-3. hullám

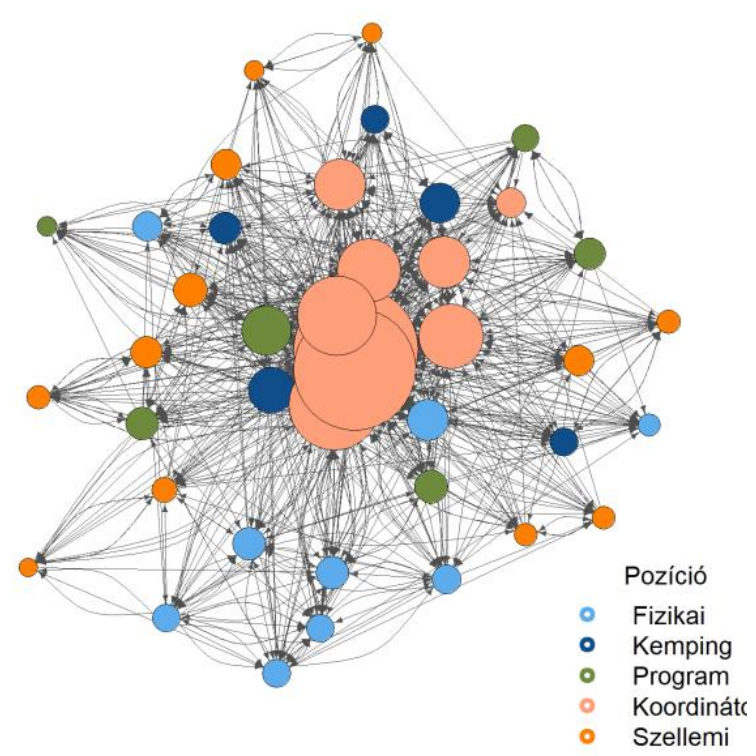

Jó együttmüködés 1-3. hullám

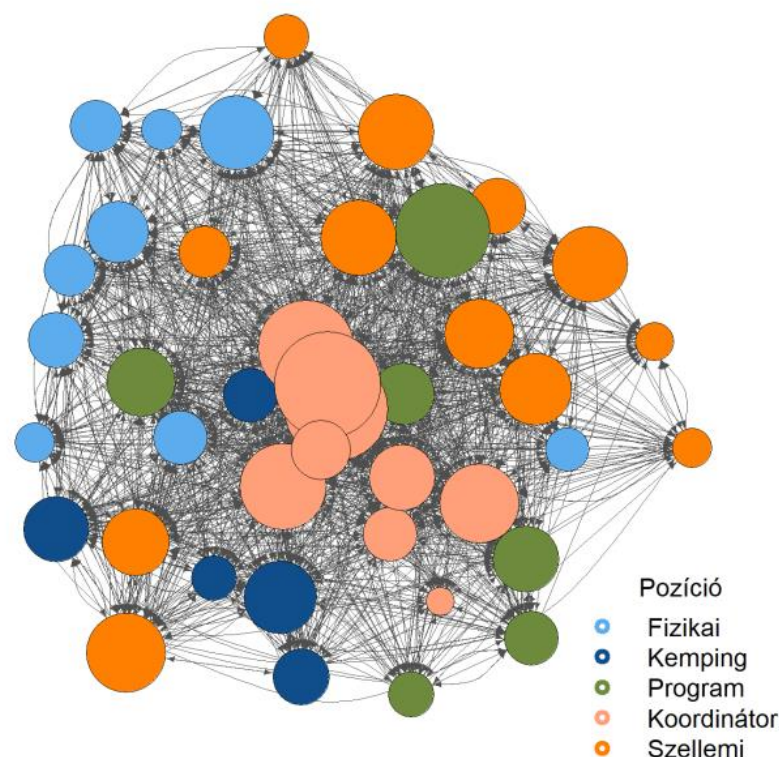

Forrás: Az ábrák a három adatfelvételi hullám eredményeit összegzik. A kötelező együttmüködést a „Munkahelyi feladataiddal kapcsolatban kivel kell együttmúködnöd?” kérdéssel mértük. A jó együttmúködést a „Kivel szoktál együttmüködni nem munkahelyi feladatokkal kapcsolatban?" kérdéssel mértük. A kötelező együttmüködés hálósürüsége 37 százalék, a jó együttmüködésé 60 százalék.

Tapasztalataink alapján a fesztiválönkéntességben a mentor pozíció kiváló terepe a csapatmunka szabályainak elsajátításának, illetve a gyors reakciót igénylő környezethez való alkalmazkodásnak: „Az ember csapatban dolgozik, megtanulja, hogy hogyan kell kommunikálni másokkal, hogy el kell számolni tízig és csak utána odaszólni valakinek, mert 
különben abból egy komoly sértődés lesz. ...Igyekszem odafigyelni más emberekre - ha valami bajom van, az véletlenül se rajtuk csapódjon le."11.

Ugyanakkor a csoportformálódás középtávú mechanizmusaira is fény derült: a klikkesedés témája ellentmondásos dimenziót alkot a kommunikációban, pozitív és negatív végpontokkal: „Itt mindenki jóban van mindenkivel, nincs ilyen klikkesedés." „Alapvetően csoportosulási kérdés, hogy biztos vagyok benne, hogy klikkesedik mindenki." "Vannak csoportosulások, de ez nem abban merül ki, hogy másokkal nem is hajlandóak szóba állni." 12

\section{Elköteleződés}

Az együttmúködéssel kapcsolatban a munkahelyi elégedettséget és elköteleződést is mértük a fesztivált megelőzően, közben és azt követően, a tableten kitöltött kérdőíves felmérés során (3. ábra). Eredményeink alapján elmondható, hogy a mentorok és koordinátorok elégedettnek és elkötelezettnek mutatkoztak. Az elégedetlenség, ha meg is jelent, nem terjedt a hálóban, vagyis 3-4 esetről volt szó a különböző csoportokban. Az elköteleződés - az informális együttmúködési hálóra vetítve - a munkahelyi elégedettséghez képest erősebbnek tűnt a három adatfelvételi hullám összesített adatai alapján.

A fiatalok tudatában voltak felelősségüknek és reflektáltak rá: „Vannak a kötelességeim, és nekem ez van legelöl, mert tudom, hogy én így ezt vállaltam." "Majd hisztizek otthon, ha vége van." „Önmagában kihívás, hogy egyedül kell koordinálnom egy harmincfös csapatot."13 Klasszikus - szülö-gyerek - és a modern, partneri attitűd is jelen volt a csoportvezetők hozzáállásában. „Vigyázok az önkénteseimre, mintha a saját gyerekeim lennének." "Gondoskodom tulajdonképpen a kisgyermekeimröl." „A kedvességem kifizetődött, mert most, ha már kérek tölük valamit, nem az van, hogy nekiállnak hisztizni, hanem igyekeznek partnerként müködni benne." 14

\footnotetext{
11 Idézet a mentorokkal készített interjúkból.

12 Idézet a mentorokkal készített interjúkból.

${ }^{13}$ Idézetek a mentorokkal készített interjúkból.

14 Idézetek a mentorokkal készített interjúkból
} 
3. ábra Az elégedettség és elköteleződés az informális együttmüködés kapcsolathálójában a koordinátorok és mentorok esetében a Sziget Fesztivált megelözően, közben és végén, 2018-ban.
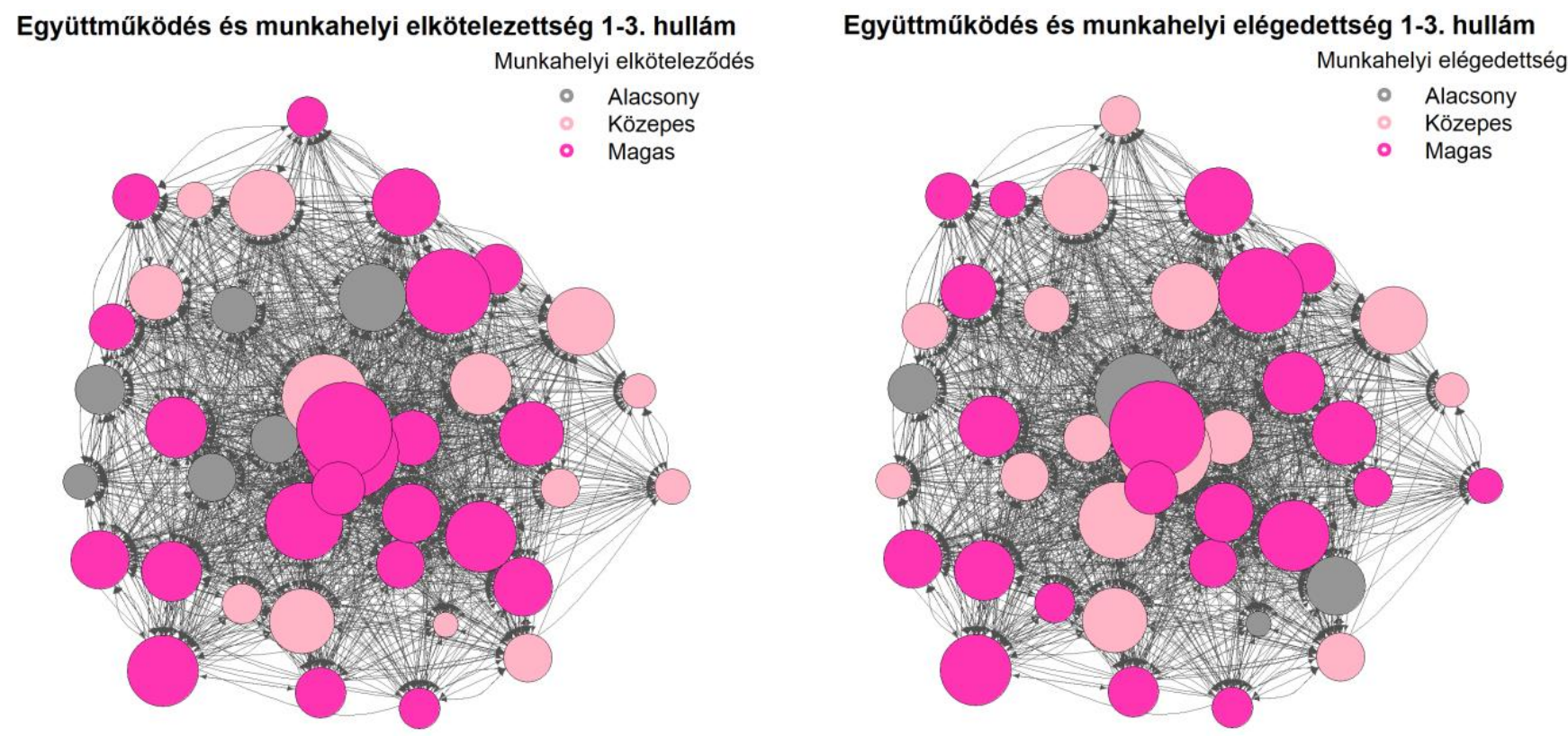

Forrás: Az ábrák a három adatfelvételi hullám eredményeit összegzik. Az elégedettséget és elköteleződést két kiterjedtebb kérdésblokkal mértük.

\section{Kommunikáció}

A mentorok formális és informális kommunikációját naponta kétszer kérdeztük meg a Sziget Fesztivál ideje alatt, az okosórákon történő kérdőíves felmérés során. Összesen 25 adatfelvételi pont keletkezett (augusztus 2 . délután - augusztus 14. délután), melyeket 16:00kor választottunk el egymástól (a 16:00 előttieket délelőtti adatfelvételnek, a 16:00 utániakat délutáni adatfelvételnek tekintettük). A napi kérdőívek esetében a válaszadás körülbelül 80 százalékos volt, a szabadnapok és egyéb programok miatt ki nem töltött kérdőíveket hiányzó adatként tekintettük. Eredményeink azt mutatják, hogy a mentorok több jelölést kaptak és adtak a személyes beszélgetés hálójában, mint a munka témájúban. Mindez azt jelzi, hogy bár a mentorok csoportja egy konkrét feladat megoldása céljából szerveződött, a konkrét feladat megoldásán felül is intenzív kommunikációt folytattak egymással a hálózat szereplői. Továbbá, a személyes beszélgetések kialakulása nem feltétlen kötődött közvetlen módon munkával kapcsolódó beszélgetésekhez: bár megfigyelhető volt az együttjárás a kétféle kommunikáció között, ennek mértéke ingadozó és egyik mérési pontban sem volt kifejezetten erős. Volt egyegy kiemelkedő szereplője a beszélgetések hálózatának, azonban senki sem szorult 
perifériára, noha személyes beszélgetések szempontjából nagyobb volt a bejövő jelölések szórása a szereplők között, mint a munkahelyi témájú beszélgetések esetében. A teljes adatfelvétel idejére összegezve elmondható, hogy egy mentort átlagosan 63,1-szer jelöltek társai személyes beszélgetés szempontjából partnerként a fesztivál időszaka alatt $(S D=22,1)$ és átlagosan 38,7-szer munkahelyi beszélgetés szempontjából ( $S D=15,7)$.

4. ábra A formális és informális beszélgetések megoszlása a mentorok esetében a Sziget Fesztivál ideje alatt, 2018-ban.

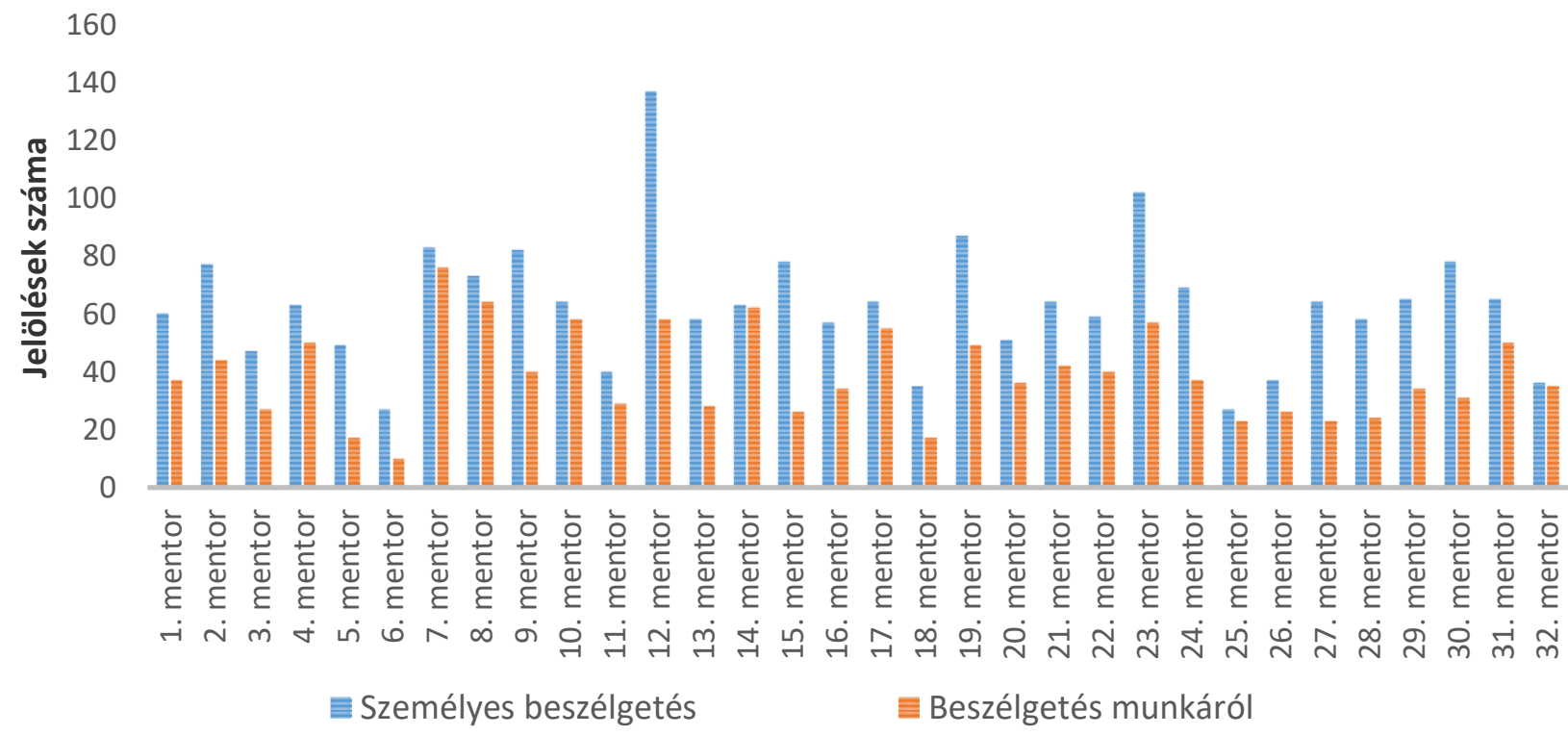

Forrás: Az ábrák az összes adatfelvételi pont eredményeit összegzik. A kérdőíveket minden nap délelőtt és délután okosórákon töltötték ki a résztvevők a "Kivel folytattál SZEMÉLYES beszélgetést az elöző lekérdezés óta?”, illetve „Kivel folytattál MUNKAHELYI FELADATAIDDAL KAPCSOLATBAN beszélgetést az előző lekérdezés óta?”.

A kommunikációs csatornákat illetően, a mentorok előtérbe helyezték a gyors csetcsatornákat: Facebook csoportbeli cset, Messenger. Ezeken a csatornákon kifejezetten a munkával kapcsolatos információkat, illetve az üzenetekre adott reakciókat közölték, utóbbiaknak erős motivációs értéke is volt. Azonban a személyes kommunikációnak is nagy jelentősége volt, a mentorirodában sokat beszélgettek a munkáról és egymásról is: „Mindenki nagyon sok idöt tölt a mentorirodában vagy környékén... Mi csináltunk olyat, hogy leültünk este páran pletykálni a sátor elött, ki mit tud, és akkor meséltek. Azért már lement két fesztivál, vannak sztorik."15

\footnotetext{
${ }^{15}$ Idézet a mentorokkal készített interjúkból.
} 


\section{AZ ESETTANULMÁNY TANULSÁGAI, JAVASLATOK A SZERVEZETI VEZETŐK FELÉ}

Eredményeink rávilágítottak arra, hogy a fesztivál önkéntes szervezetnek egyszerre kell megfelelnie egyéni szintű (önkéntesek, mentorok) és szervezeti szintű elvárásoknak.

Az egyéni szintű elvárások esetében a FÖK kifejezetten sok energiát fordított arra, hogy felmérje a programba jelentkezők életkorát, tudását, motivációját, képességeit és fizikai állapotát. Ezáltal próbálták biztosítani azt, hogy az önkéntesek és mentorok a számukra lehetséges legoptimálisabb munkabeosztást kapják. Az egyéni szintű elvárásokban előforduló eltéréseket a FÖK a transzparens kommunikációval biztosította, és igyekezett megfelelően tájékoztatni az önkéntes programban résztvevőket.

Szervezeti szinten azt tapasztaltuk, hogy bár a mentorok jóval többet „nyertek” a programtól a munkaerőpiacon is hasznosítható készségek elsajátítása szempontjából, ugyanakkor számukra sokkal fárasztóbb és terhelőbb volt a munka. A mentorok csupán 4 százalékát tették ki a teljes önkéntes csapatnak és ez a létszám kevésnek bizonyult. Bár nincs konkrét tapasztalatunk a mentorok optimális létszámát illetően egy önkéntes szervezetben, de úgy véljük, hogy szervezeti szinten a mentorok létszámának az egész önkéntes csapat körülbelül 10 százalékát kellene lefednie.

A Fesztivál Önkéntes Központ - mint önkénteseket foglalkoztató szervezet - roppant sajátos emocionális karakterisztikával jellemezhető a „munkáltatói márka” tekintetében, hiszen az önkéntesség (akár mint társadalmi cselekvés) is egy brand, a fesztivál is az, és a Sziget is. Így a munkavégzés aspektusából erőteljes love brand ${ }^{16}$ - szeretem-márka - jelenlétet tapasztalhatunk. Ennek értelmezésekor figyelembe kell venni a kutatás által érintett korosztálynak az átlagosnál intenzívebb emocionális és interperszonális késztetéseit, motivációit.

Éppen ezek a motivációk magyarázzák a munkavégzés során létrejövő, a kapcsolatháló alapján, a kapcsolatok és a teljes közösség szintjén is tapintható kohéziót. A kohézió igen értékes potenciál az önkéntesség területén, hiszen egyik meghatározó forrása a közös teljesítménynek, hatékonyságnak, sőt, akár a közösségen belüli értékszocializációnak is. Éppen ezért nem hagyható figyelmen kívül a kapcsolathálózati kutatás által feltárt formális és informális aspektus: ebből válik érthetővé, hogy az ilyen jellegű szervezetekhez nem

\footnotetext{
${ }^{16}$ Love brand - olyan márka, melyet a fogyasztók szeretnek, emocionális kötődnek hozzá.
} 
közelíthetünk a hagyományos, vertikális-horizontális megközelítéssel a hierarchia tekintetében. A lapos hierarchiában a mentor és az önkéntes interperszonális kapcsolata hordozza a top-down ${ }^{17}$ és bottom-up ${ }^{18}$ információáramlás általában több szinten megjelenő dinamikáját, így a konfliktusok kezelésének is más network-kontextusa lesz.

A mentor - önkéntes kapcsolat számos sajátossága tipizálható, általánosan megjelenőként jellemezhető. A középvezetői szinttel való azonosulás a feladattudatosságot növeli, a csapatmunkát elősegíti. Nagy létszámú önkéntesekkel működő szervezetek esetében a mentor szint múködtetése elkerülhetetlen, hiszen javítja az információáramlást, a tudástranszfert és segítségnyújtást. Ennek az ismeretnek a birtokában a feltárt kapcsolatok sokasága - vagyis maga a hálózat - is jobban értelmezhető, például a rejtett érzelmek, percepciók, attitűdök tekintetében.

A kapcsolathálózati elemzés elsődleges értéke abban van egy önkénteseket foglalkoztató szervezet számára is, hogy rámutat a klasszikus feladat-vezető és az érzelmi vezető funkcióinak az önkéntes-közösségében való megjelenésére, és ennek ismeretében sikeresebb és eredményesebb vezetői döntések alakíthatóak ki. Továbbá, a kapcsolatháló eredményeinek segítségével finomhangolható az interperszonális kötődésektől soha nem független szervezeti elköteleződés, és nemcsak a fesztiválhoz, hanem az elvégzett önkéntes munka magas színvonalához kapcsolódóan is. Ezeknek a közösségi értékeknek a rendszeres monitorozásával, vagyis az évente elvégzett kapcsolatháló kutatással kirajzolhatóak azok, a reputációt és hierarchiát leíró mintázatok, melyek figyelembevételével az önkéntes szervezetvezetése megfelelő döntéseket tud hozni - a szervezet és az önkéntesek közötti kooperáció optimalizálása érdekében.

\section{IRODALOM}

Cnaan, Ram A. - Cascio, Toni A. (1998): Performance and commitment: Issues in management of volunteers in human service organizations. Journal of Social Service Research, 24(3-4) pp. 1-37.

Frenette, Alexandre (2013): Making the intern economy: Role and career challenges of the music industry intern. Work and Occupations, 40(4) pp.364-397.

Gjelsvik, Martin (2002): Hotels as learning arenas. Scandinavian Journal of Hospitality and Tourism, 2(1) pp. 31-48.

\footnotetext{
17 Top-down: felülröl lefelé irányuló

${ }^{18}$ Bottom-up: alulról felfelé irányuló
} 
Joseph, John - Klingebiel, Ronald - Wilson, Alex James (2016): Organizational structure and performance feedback: Centralization, aspirations, and termination decisions. Organization Science, 27(5) pp. 1065-1083.

Morrison, Elizabeth Wolfe (2002): Newcomers' relationships: The role of social network ties during socialization. Academy of Management Journal, 45(6) pp. 1149-1160. 